\title{
Professional standards for training of teachers to ensure the quality of education in a city
}

\author{
Nataliya Nikolayeva $^{1 *}$, Nikolay Mikhaylov ${ }^{1}$, Svetlana Semenova ${ }^{1}$, Elvira Mikhaylova ${ }^{1}$, and \\ Yelena Derevleva ${ }^{1}$ \\ ${ }^{1}$ Moscow City University, Institute of Natural Sciences and Sports Technologies, Moscow, Russia
}

\begin{abstract}
The conducted research has allowed identifying the main contradictions between educational and professional standards in the field of training of teachers and determining the most vulnerable links in ensuring a systematic approach to the organization of the educational process. The conducted analysis has resulted in a scientific justification of the necessary changes and reconciliations in educational and professional standards to update them and improve the quality of training of specialists in the teaching sector. An earlier analysis of federal educational standards has shown that changes in the content of competencies were aimed at implementing education as a service rather than a pedagogical process. This makes it difficult for the teaching staff to educate the younger generation of teachers in the traditional paradigm of national education. However, the latest generation of Federal State Educational Standards (FSES) indicates the need to take into account the requirements of professional standards that correspond to the professional activities of graduates. Besides, clause 3.5 of the FSES $3++$ specifies the right of an educational organization "not to include professional competencies determined independently if there are mandatory professional competencies, as well as if the recommended professional competencies are included in the bachelor's program" (Order of the Ministry of Education and Science of the Russian Federation of December 4, 2015 No. 1426). There is an evident discrepancy of requirements of the FSES of the last generation in terms of the scope of professional competences and the need to take into account these requirements to ensure teacher's actions, presented in the professional standards, aimed at performing official duties by the teacher that allows considering the problem of compliance with the requirements proposed in the FSES and in professional standards of teachers to be very relevant. The research purpose is to conduct a comparative analysis of the requirements stated in the FSES and professional standards of teachers in the national education system.
\end{abstract}

Keywords: pedagogical activity, professional competencies, pedagogical education, physical culture.

* Corresponding author: nikolaevani@mgpu.ru 


\section{Introduction}

The effectiveness of the training system of specialists in any industry is dependent on a clear correlation between professional requirements and educational paradigms, compliance of the content and goals of the educational process with the professional requirements [1-5]. At that, the more mutually determining the compliance of professional education with the professional qualifications, the more effectively, in terms of sustainable development, the entire educational system will function, ensuring the competitiveness of graduates in constantly changing conditions of life-sustaining activity $[6,7]$.

\section{Methods}

The study provides for analyzing scientific, methodological, and regulatory literature, comparative analysis, as well as content analysis of the teacher's professional standards.

In the field of the professional pedagogical activity, two professional standards have been implemented and are currently in effect (Table 1), whose content has been subjected to comparative analysis in terms of the requirements for a teacher to perform labor actions $[8,9]$.

Table 1. Professional standards related to the teacher's activity.

\begin{tabular}{|c|c|c|}
\hline No. & $\begin{array}{c}\text { Standard } \\
\text { Code }\end{array}$ & Title of the professional standard \\
\hline 1. & 01.001 & $\begin{array}{c}\text { Professional standard "Teacher", approved by the order of the Ministry of } \\
\text { Labor of the Russian Federation of 18.10.2013, No. 544n (as amended on } \\
25.12 .2014)\end{array}$ \\
\hline 2. & 01.003 & $\begin{array}{c}\text { Professional standard "Teacher of additional education for children and } \\
\text { adults", approved by the order of the Ministry of Labor and Social } \\
\text { Protection of the Russian Federation of 5.05.2018, No. 298n }\end{array}$ \\
\hline
\end{tabular}

\section{Results and discussion}

The target settings of the above standards are presented in Table 2 according to the titles of the base groups, positions (profession), or specialty.

The All-Russian Classifier of Occupations OK 010-93 (ARCO) became invalid on July 1, 2015. In this regard, the types of professional activities listed in Tables 2, 3, and 4 related to this Classifier of Occupations are invalid.

As can be seen from Table 2, the goals specified in professional standards differ, at that, they are diametrically opposite. In Standard 1, the goal is to provide educational services in the general education system, which orients the majority of teachers to market relations in the education sector. In Standard 2, the goal is focused on the development of children's creative abilities.

The kinds of professional activities presented in Table 2 according to the professional standard "Teacher" (1) include the training of teachers in the system of special education and teaching staff of special training. These levels of education are not represented in law No. 273-FZ [10]. 
Table 2. Target settings of professional standards and corresponding types of professional activities.

\begin{tabular}{|c|c|c|c|}
\hline No. & Goal & $\begin{array}{l}\text { Professional } \\
\text { standard } \\
\text { code }\end{array}$ & Kinds of professional activities \\
\hline 1 & $\begin{array}{c}\text { Providing educational services on } \\
\text { basic general education programs } \\
\text { by educational organizations } \\
\text { (organizations that provide } \\
\text { teaching) }\end{array}$ & 01.001 & $\begin{array}{l}\text { Teachers in secondary schools } \\
\text { (ARCO); } \\
\text { Preschool education and training } \\
\text { staff (ARCO); } \\
\text { Teachers in the special education } \\
\text { system (ARCO); } \\
\text { Special education teaching staff } \\
\text { (ARCO); } \\
\text { Primary education teaching staff } \\
\text { (ARCO) }\end{array}$ \\
\hline 2 & $\begin{array}{l}\text { Organizing students' activities } \\
\text { to acquire knowledge, develop } \\
\text { skills and competencies; } \\
\text { Creating pedagogical conditions } \\
\text { for the formation and development } \\
\text { of creative abilities of children and } \\
\text { adults, meeting their individual } \\
\text { needs for intellectual, moral, and } \\
\text { physical improvement, health } \\
\text { promotion, and spare time } \\
\text { management; } \\
\text { Adapting children to live in } \\
\text { society, to their professional } \\
\text { orientation, identifying and } \\
\text { supporting children who have } \\
\text { shown outstanding abilities; } \\
\text { Ensuring that students achieve } \\
\text { the standard results of mastering } \\
\text { additional general education } \\
\text { programs }\end{array}$ & 01.003 & $\begin{array}{l}\text { Teachers in secondary schools } \\
\text { (ARCO); } \\
\text { Specialists in teaching methods } \\
\text { and upbringing work (2351); } \\
\text { Teacher of additional education } \\
\text { (including the senior teacher) } \\
\text { (QRB) }{ }^{\dagger} \text {; } \\
\text { Senior teacher of additional } \\
\text { education; } \\
\text { Coach-instructor (including the } \\
\text { senior coach-instructor) } \\
\text { Senior coach-instructor } \\
\text { Teacher (QRB); } \\
\text { Additional education teacher } \\
\text { (ARCWPE) } \\
\text { Sports coach-instructor } \\
\text { (ARCWPE) }\end{array}$ \\
\hline
\end{tabular}

Standard 1 identifies two generalized job functions, which represent pedagogical activities aimed at designing and implementing the educational process, as well as pedagogical activities aimed at designing and implementing educational programs. The implementation of these job functions is supported by the $5^{\text {th }}$ and $6^{\text {th }}$ qualification levels. The $5^{\text {th }}$ qualification level corresponds to secondary professional education, while the $6^{\text {th }}-$ to bachelor's program (Table 3).

Standard 2 distinguishes three generalized job functions that make requirements for the qualification of a teacher of the $6^{\text {th }}$ level. It seems to the authors that the presented functions require higher level of qualification (Table 4).

The specified number of generalized job functions in the professional standard "Teacher" is illogical. According to law No. 273-FZ, the education system provides for continuous education throughout life, and it would be more correct to supplement the generalized job functions of this standard according to the types of activity of the teacher and the level of his qualification.

Qualification reference book for managers, specialists and other employees

* All-Russian classifier of workers professions, employees posts and tariff categories 
Table 3. Job titles when performing generalized job functions according to the professional standard

"Teacher".

\begin{tabular}{|c|c|c|c|}
\hline \multirow{2}{*}{$\begin{array}{c}\text { Qualifi- } \\
\text { cation level }\end{array}$} & \multicolumn{2}{|l|}{ Title } & \multirow[b]{2}{*}{ Additional qualities } \\
\hline & Generalized job functions & Job titles & \\
\hline 5,6 & $\begin{array}{l}\text { A. Teaching activities on } \\
\text { designing and implementing } \\
\text { the educational process in } \\
\text { educational organizations of } \\
\text { preschool, primary general, } \\
\text { basic general, and } \\
\text { secondary general education }\end{array}$ & $\begin{array}{l}\text { Teacher } \\
\text { (QRB) } \\
\text { Tutor } \\
\text { (QRB) }\end{array}$ & $\begin{array}{c}\text { Teachers in secondary schools } \\
\text { (ARCO); } \\
\text { Teachers in the special education } \\
\text { system (ARCO); } \\
\text { Primary education teaching staff } \\
\text { (ARCO); } \\
\text { Preschool upbringing and education } \\
\text { staff (ARCO); } \\
\text { Special education teaching staff } \\
\text { (ARCO); }\end{array}$ \\
\hline 6 & $\begin{array}{l}\text { B. Teaching activities on } \\
\text { designing and implementing } \\
\text { basic general education } \\
\text { programs }\end{array}$ & $\begin{array}{l}\text { Teacher } \\
\text { (QRB) } \\
\text { Tutor } \\
\text { (QRB) }\end{array}$ & $\begin{array}{c}\text { Teachers in secondary schools } \\
\text { (ARCO); } \\
\text { Teachers in the special education } \\
\text { system (ARCO); } \\
\text { Primary education teaching staff } \\
\text { (ARCO); } \\
\text { Preschool upbringing and education } \\
\text { staff (ARCO); } \\
\text { Special education teaching staff }\end{array}$ \\
\hline
\end{tabular}

The position titles of "Teacher" and "Educator" shown in Table 3 can be divided by the level of education. Less clear is the content of the Table, which provides additional characteristics of the types of teaching activities in the standard, namely, primary education teaching staff and pre-school upbringing and education staff. Exactly what kind of staff, other than teachers and tutors, do professional standard developers have in their minds?

For teachers of additional education, the professional standard specifies generalized job functions: A, B, and C. Such division of job functions indicates that some teachers will manage other organizationally or methodically that requires higher level of education (qualification) (Table 4).

The group of activities specified in professional Standard 2, namely, teachers for additional training programs, raises questions. There are no such programs in Federal law "On education in the Russian Federation" [10]. There are programs of additional education at different levels. The group of activities "Specialists in teaching methods" is not presented anywhere in any way. Who are these specialists, whether methodologists, trainers, teachers of various specialties, specialists engaged in the department of education? The positions presented in the two analyzed professional standards (1 and 2) do not correspond to the positions indicated in the QRB [11].

Since January 1, 2017, the order of the Ministry of Labor of Russia [8] establishes that the professional standard "Teacher" is used by employers when forming personnel policy, organizing training and certification of employees, concluding employment contracts, developing job descriptions, and establishing wage systems.

Today, the labor market is characterized by an obvious contradiction between the professional competence of graduates and the existing employer's request for their training. The higher education system is focused on the requirements of the government and the population, which can often contradict the employers' requirements [5]. International studies show that the inertia of education, despite the active supply and demand, creates a long-term imbalance in the competencies that are formed in the educational environment $[12,13]$. In Russian education, fundamental knowledge prevails over practical skills, 
though the latter is in high demand among employers. Therefore, detailed monitoring of the required skills, and the formation of professional competencies for new educational standards on their basis, should ensure the smoothing of contradictions in the educational sector $[14,15,16]$.

Table 4. Positions or specialties according to the job functions (professional standard "Teacher of additional education").

\begin{tabular}{|c|c|c|c|}
\hline $\begin{array}{c}\text { Qualification } \\
\text { level }\end{array}$ & $\begin{array}{l}\text { Generalized job } \\
\text { functions }\end{array}$ & Job titles & $\begin{array}{l}\text { Title of the base group, position } \\
\text { (profession), or specialty }\end{array}$ \\
\hline 6 & $\begin{array}{l}\text { A. Teaching based } \\
\text { on additional general } \\
\text { education programs }\end{array}$ & \begin{tabular}{|} 
Teacher of \\
additional education; \\
Senior teacher of \\
additional education; \\
Coach-instructor; \\
Senior coach- \\
instructor; \\
Teacher
\end{tabular} & $\begin{array}{c}\text { Teachers of additional education (QRB); } \\
\text { Teacher of additional education } \\
\text { (including the senior teacher) (QRB); } \\
\text { Teacher of additional education } \\
\text { (ARCWPE); } \\
\text { Coach-instructor (including senior coach- } \\
\text { instructor) (QRB); } \\
\text { Teacher (QRB); } \\
\text { Sports coach-instructor (QRB, } \\
\text { ARCWPE); } \\
\text { Pedagogy of additional education } \\
\text { (JACS) } \\
\S\end{array}$ \\
\hline 6 & $\begin{array}{l}\text { B. Organizational } \\
\text { and methodological } \\
\text { support to } \\
\text { implement } \\
\text { additional general } \\
\text { education programs }\end{array}$ & Methodist & $\begin{array}{l}\text { Methodist (QRB, ARCWPE); } \\
\text { Methodist of extracurricular institution } \\
\text { (ARCWPE); } \\
\text { Methodist of the educational institution, } \\
\text { methodical, educational-methodical } \\
\text { center, or film library (ARCWPE); } \\
\text { Pedagogy of additional education (JACS) }\end{array}$ \\
\hline 6 & $\begin{array}{l}\text { C. Organizational } \\
\text { and pedagogical } \\
\text { support for the } \\
\text { implementation of } \\
\text { additional general } \\
\text { education programs }\end{array}$ & Facilitator & $\begin{array}{l}\text { Teachers of additional training programs } \\
\text { (ARCO); } \\
\text { Facilitator (QRB, ARCWPE); } \\
\text { Pedagogy of additional education (JACS) }\end{array}$ \\
\hline
\end{tabular}

Following the Federal program for the modernization of pedagogical education in the Russian Federation, pilot models of students' academic mobility are currently being developed, namely, mechanisms for drawing up an individual educational trajectory in the framework of a single educational institution and one training period are being worked out. An important place in this process is occupied by the OECD's "* international platform "The Future of Education and Skills: Education 2030", created in 2018 [17]. However, all these projects require scientific discussion, justification, and must be tested at different levels.

\section{Conclusion}

None of the analyzed standards presents professional competencies; this does not allow linking the requirements specified in the FSES and professional standards. Training specialists in the positions listed in the professional standards is carried out through Master's, postgraduate, and additional professional education programs. In the system of

$\S$ Joint Academic Coding System

** Organization for Economic Co-operation and Development 
additional professional education, new qualifications are assigned only after completion of professional retraining programs.

Since professional standards do not define professional competencies and corresponding qualification skills, it is impossible to distinguish positions and determine the scope of work performed according to the position.

\section{References}

1. Order of the Ministry of Education and Science of the Russian Federation of December 4, 2015 No. 1426 "On the approval of the federal state educational standard of higher education in 44.03.01 Pedagogical education (bachelor's level)" (2015). Accessed on: December 20, 2020. [Online]. Available: http://base.garant.ru/71300970/

2. S.A. Pilipenko, A.A. Zhidkov, Ye.V. Karavaeva, A.V. Serova, Higher education in Russia, 6, 5-15 (2016)

3. V.S. Senashenko, Higher education in Russia, 27(3), 38-47 (2018)

4. Kh.G. Tkhagapsoev, M.B. Sapunov, Higher education in Russia, 6, 87-97, (2016)

5. M.Yu. Shchennikova, Uchenyye zapiski universiteta imeni P.F. Lesgafta, 9(175), 344350, (2019)

6. N.G. Mikhaylov, N.I. Nikolayeva, Uchenyye zapiski universiteta imeni P.F. Lesgafta, 7(185), 254-263 (2020)

7. N.I. Nikolayeva, Theoretical and methodological substantiation of the content of higher education in the field of physical culture and sports (Moscow, 2020)

8. Order of the Ministry of Labor and Social Protection of the Russian Federation of October 18, 2013 No. 544n "On the approval of the professional standard "Teacher (pedagogical activity in the field of preschool, primary general, basic general, secondary general education (educator, teacher))" (2013). Accessed on: December 20, 2020. [Online]. Available: http://fgosvo.ru/uploadfiles/profstandart/01.001.pdf

9. Order of the Ministry of Labor and Social Protection of the Russian Federation of May 5, 2018 No. 298n "On the approval of the professional standard "Teacher of additional education for children and adults," (2018). Accessed on: December 20, 2020. [Online]. Available: https://www.garant.ru/products/ipo/prime/doc/71932204/

10. Law "On Education in the Russian Federation": Federal Law of December 29, 2012 No. 273-FZ (as amended on July 26, 2019) (2019). Accessed on: December 20, 2020. [Online]. Available: http://www.kremlin.ru/acts/bank/36698

11. Qualification reference book for managers, specialists and orther employees (QRB), 2018. Edition of April 9, 2018 (including with changes entered into force on 01.07.2018) (2018). Accessed on: December 20, 2020. [Online]. Available: https://classinform.ru/eksd.html

12. A.P. Gorina, European research studies journal, 19(3B), 227-238 (2016)

13. R. Bazhenov, N. Bazhenova, L. Khilchenko, M. Romanova, Procedia - Social and Behavioral Sciences, 214(5), 103-111 (2015)

14. V.I. Blinov, I.S. Sergeev, Pedagogika, 83(11), 5-24 (2019)

15. Information and analytical materials based on the results of monitoring the efficiency of educational institutions of higher professional education Accessed on: December 20, 2020. [Online]. Available: miccedu.ru/monitoring\%20/2018/_vpo/inst.php?id=1755 (Date of access: 06.08.2020).

16. A. Shokhin, Educational policy, 1(67), 15-21 (2015) 
17. OECD (2018) The Future of Education and Skills: Education 2030. Retrieved from https: // www.oecd.org/education/2030-project/about/ 